\title{
DE OPBRENGST DER SUCCESSIEBELASTING IN 1900.
}

De opbrengst der successiebelasting was, naar bekend is, in 1900 hoog, zelfs hooger dan ooit het geval was.

De successierechten beliepen in ronde eijfers in de jaren $1890-1900$ :

$\begin{array}{llllll}1890 & \text { f } 11.277 .000 & 1896 & \text { f } 11.618 .000 \\ 1891 & \text { " } 13.667 .000 & 1897 & \text { " } 11.428 .000 \\ 1892 & \text { " } 15.084 .000 & 1898 & \text { " } 10.869 .000 \\ 1893 & \text { " } 11.059 .000 & 1899 & \text { " } 13.078 .000 \\ 1894 \text { " } 11.959 .000 & 1900 & \text { " } 15.495 .000 \\ 1895 & \text { " } 12.705 .000 . & & & \end{array}$

Een blik in de Jaarcijfers doet zien, dat de opbrengst in 1890 vrij normaal was. $\mathrm{Zij}$ verschilde weinig van die van vorige jaren, toen zij eveneens ruim $f 11$ millioen bedroeg. Ook in de volgende jaren bleef de opbrengst, gelijk vorenstaande cijfers aantoonen, herhaaldelijk op dit peil. In 1895 was eenige stijging waar te nemen, maar in $1899-1900$ vindt evenals in de jaren $1891-1892$ eene vrij belangrijke vermeerdering van opbrengst plaats.

Laat zich de oorzaak dier hooge opbrengst in 1900 uit de beschikbare statistische gegevens nasporen?'

Verschillende oorzaken laten zich denken. Toevallig kunnen eenige zeer belangrijke nalatenschappen in dien tijd zijn opengevallen. Of wel de sterfte kan gestegen zijn, hetzij onder de gansche bevolking, lictzij voornamenlijk alleen onder de meervermogenden. En liet is ook mogelijk, dat ecn betrekkelijk groot aantal nalatenschappen in de zijlinie of door nietannverwanten werd geërfd. Elk dezer omstandigheden kan in meerdere of mindere mate invloed hebben doen gelden.

De vorige minister van financiën, de heer Pierson, scheen te oordeelen naar zijne rede in de vergadering der Eerste Kamer 
der Staten-Generaal van 29 Januari 1901 , de oorzaak vooral te zoeken in het openvallen van eenige groote nalatenschappen. Hij noemde de opbrengst wisselvallig, wijl niet telken jare hetzelfde aantal gros bonnets stierven. Die omstandigheid mag invloed hebben gehad, zij was buiten twijfel niet de eenige of vooruaamste oorzaak. Aanzienlijke nalatenschappen doen uit den aard der zaak de opbrengst stijgen, maar het verschil met de opbrengst der vorige jaren is te belangrijk, dan dat het uitsluitend of zelfs hoofdzakelijk een gevolg zou zijn van enkele groote posten.

De zuivere saldo's der nalatenschappen, waarover successierecht is betaald, bedroegen in de jareu

$\begin{array}{llll}1890 & \mathrm{f} 248.725 .000 & 1896 & \text { f } 232.724 .000 \\ 1891 & \text { "289.294.000 } & 1897 & \text { "224.724.000 } \\ 1892 & \text { " } 309.866 .000 & 1898 & \text { " } 214.457 .000 \\ 1893 & \text { "229.744.000 } & 1899 & \text { " } 252.364 .000 \\ 1894 & \text { "257.976.000 } & 1900 & \text { "295.114.000 } \\ 1895 \text { " } 247.816 .000 & & \end{array}$

Nederland telt weinig bezitters van vele millioenen, zoodat verschillen van $\mathrm{f} 80$ millioen als tusschen de jaren 1892 en 1893 , 1898 en 1900 voorkomen, niet uitsluitend of zelfs voornamenlijk in het openvallen van eeuige groote nalatenschappen in de jaren 1892 en 1900 hunne verklaring vinden.

Vergelijkt men het aantal nalatenschappen, waarvan in de jaren 1890 - 1900 successierecht is betaald, dan ziet men onmiddelijk, dat het aantal in de jaren 1892 en 1900 , toen de opbrengst groot was, ook bijzonder hoog was. Het aantal bedroeg in

$\begin{array}{rrrr}1890 & 10.090 & 1896 & 8.919 \\ 1891 & 9.734 & 1897 & 8.982 \\ 1892 & 11.195 & 1898 & 9.154 \\ 1893 & 8.363 & 1899 & 9.507 \\ 1894 & 9.977 & 1900 & 11.101 \\ 1895 & 9.226 & & \end{array}$

Het gemiddeld zuivere saldo der nalatenschappen was in 1900 niel hoog.

$\begin{array}{llll}1890 & f 24.650 & 1896 & \text { f } 26.100 \\ 1891 & \text { " } 29.720 & 1897 & \text { " } 25.910 \\ 1892 & \text { " } 27.670 & 1898 & \text { " } 23.420 \\ 1893 & \text { " } 27.471 & 1899 & \text { " } 26.540 \\ 1894 & \text { " } 26.857 & 1900 & \text { " } 26.580 \\ 1895 & \text { " } 26.860 & & \end{array}$


Het jaar 1900 onderscheidt zich dus door eene zeer hooge totaalopbrengst, geheven van een groot aantal ualatenschappen, die gemiddeld van een betrekkelijk normaal bedrag zijn.

Merkwaardig is, dat de ophrengst hooger is dan in 1892, hoezeer het aantal nalatenschappen en haar gemiddeld bedrag geringer is dan destijds.

En vooral merkwaardig is het ook in 1892 waargenomen feit, dat het aantal nalatenschappen betrekkelijk aanmerkelijk hooger was dan in andere jaren.

Het feit, dat het aantal nalatenschappen, waarvan successierecht is betaald, hoog was, doet vermoeden, dat de sterfte grooter was dan in vorige jaren.

Inderdaad is dit het geval.

\begin{tabular}{|c|c|c|c|c|}
\hline Jaren. & $\begin{array}{l}\text { Gestorven } \\
\text { personen. }\end{array}$ & $\begin{array}{c}\text { Aantal } \\
\text { nolatenschappen. }\end{array}$ & $\begin{array}{l}\text { Verhouding tussc } \\
\text { nalatenschapp } \\
\text { aantal over }\end{array}$ & $\begin{array}{l}\text { hen het aantal } \\
\text { ven en het } \\
\text { ledenen. }\end{array}$ \\
\hline 1890 & 93.246 & 10.090 & 10.82 & pCt. \\
\hline J 891 & 94.844 & 9.734 & 10.26 & " \\
\hline 1892 & 97.530 & 11.195 & 11.47 & " \\
\hline 1893 & 90.372 & 8.363 & 9.25 & $"$ \\
\hline 1894 & 87.970 & 9.977 & 11.34 & $"$ \\
\hline 1895 & 90.007 & 9.226 & 10.25 & " \\
\hline 1896 & 84.291 & 8.919 & 10.58 & $"$ \\
\hline 1897 & 83.856 & 8.982 & 10.71 & $"$ \\
\hline 1898 & 85.813 & 9.154 & 10.66 & " \\
\hline 1899 & 87.319 & 9.507 & 10.87 & " \\
\hline 1900 & 91.835 & 11.101 & 12.08 & $"$ \\
\hline
\end{tabular}

Het verband tusschen het aantal gestorvenen en dat der valatenschappen is echter verre van sprekend. Vergeleken met het jaar 1899 is de stijging in het aantal nalatenschappen in 1900 betrekkelijk veel grooter dan die van het aantal overledenen. Ook doen verschillen van ongeveer $20 \mathrm{pCt}$. als tusschen de verhoudingeijfers van de jaren 1893 en 1900 bestaan haast twijfelen of tusschen het aantal overledenen en dat der nalatenschappen wel eenig verband is.

$\mathrm{Bij}$ het onderzoek behoort men evenwel tweeërlei in aanmerking te nemen.

Vooreerst, dat het successierecht niet onmiddellijk na het overlijden wordt betaald. Het wordt eerst zes manden daarna, 
in enkele gevallen zelfs nog later, gekweted. De belastingcijfers betreflen dus andere periodes dan de sterftecijfers. De rechten in één kalenderjaar betaald, zijn naar alle waarschijnlijkheid geheven vau nalatenschappen, die in het laatste semester van het voorafgegaane en het eerste semester van het loopende jaar zijn opengevallen.

Zoo in de wintermaanden eene epidemie vele personen ten grave heeft gesleept, dan zal de invloed, bij de sterfte over twee jaren verdeeld, veel geringer schijnen dan bij de opbrengst der belasting, waarbij zij in é́n jaar zich zou doen gevoelen. Eene vergelijking der cijfers van twee jaren zou dientengevolge bij de sterftecijfers nawwelijks eenig verschil behoeven aan te wijzen, terwijl het bij de opbrengst der belasting aanmerkelijk kon zijn.

En dan mag men niet voorbijzien, dat de verhouding tusschen de sterfte van de onvermogeuden en beter gestelden, wier nalatenschappen belastingplichtig zijn, niet altijd dezelfde is. Tijdelijke stijging van kindersterfte b.v. zal in de cijfers der successiebelasting niet merkbaar zijn.

Om dus zoo nauwkeurig mogelijk het verband, dat tusschen de meergenoemde eijfers mocht hestaan, na te sporen dient men de sterftecijfers te verdeelen in periodes van $1 \mathrm{Juli}-30 \mathrm{Juni}$ daaraanvolgende en de onvermogenden zooveel mogelijk te elimineeren, door b.v. de sterfte van personen beneden 20 jaar buiten rekening te laten.

Dit is geschied bij den volgenden staat.

Aantal nalatenAantal schappen, waarvan personen in het laatste jaar nalatenschappen tot het

Jaren. overleden. belasting is betaald.

1 Juli $1889-30$ Juni 1890
1 " $1890-30 " 1891$
1 " $1891-30 " 1892$
1 " $1892-30 " 1893$
1 " $1893-30 " 1894$
1 " $1894-30 " 1895$
1 " $1895-30 " 1896$
1 " $1896-30 " 1897$
1 " $1897-30 " 1898$
1 " $1898-30 " 1899$
1 " $1899-30 " 1900$

49.775

10.090

49.575

9.734

54.315

11.195

44.457

8.363

50.496

9.977

47.502

9.226

44.460

8.919

46.328

8.982

45.725

9.154

47.088

9.507

$54.72 \%$

11.101

de $2^{\text {do }}$ kolom.

$20,27 \%$
$19,63 \%$
$20,61 \%$
$18,80 \%$
$19,95 \%$
$19,42 \%$
$20,06 \%$
$19,38 \%$
$20,01 \%$
$20,18 \%$
$20,28 \%$


De hoogere opbrengst der belasting in 1900 is dus voor een groot deel een gevolg van eene stijging der algemeene sterfte in de periode 1 Juli $1899-30$ Juni 1900.

Duidelijk blijkt dit ook uit den volgenden staat, waarin het aantal nalatenschappen, waarover in de jaren 1890-1900 successiebelasting is betaald, is verdeeld in vier groepen.

Groep I. Groep II. Groep III. Groep VI. van f 300 - van f 15.000 - van f $100.000-$ van $f 500.000$

f 15.000 f f 100.000 . f 500.000 . en daarboven.

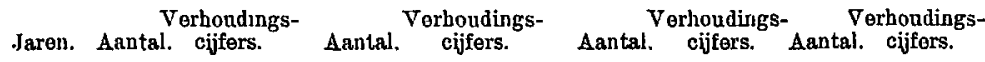

$\begin{array}{lllllllll}1890 & 74.07 & 100 & 2247 & 100 & 380 & 100 & 56 & 100\end{array}$

$\begin{array}{lllllllll}1891 & 7111 & 96 & 2196 & 97.73 & 364 & 95.78 & 63 & 112.5\end{array}$

$\begin{array}{lllllllll}1892 & 8148 & 110 & 2510 & 111.25 & 458 & 120.52 & 79 & 141.07\end{array}$

$\begin{array}{lllllllll}1893 & 6186 & 83.51 & 1787 & 79.52 & 335 & 88.15 & 55 & 98.21\end{array}$

$\begin{array}{lllllllll}1894 & 7354 & 99.28 & 2163 & 96.26 & 405 & 106.58 & 55 & 98.21\end{array}$

$\begin{array}{lllllllll}1895 & 6684 & 90.23 & 2124 & 94.52 & 360 & 94.73 & 58 & 103.57\end{array}$

$\begin{array}{lllllllll}1896 & 6588 & 88.94 & 1912 & 85.09 & 332 & 87.36 & 57 & 101.78\end{array}$

$\begin{array}{lllllllll}1897 & 6667 & 90 & 1935 & 86.11 & 322 & 84.73 & 58 & 103.57\end{array}$

$\begin{array}{lllllllll}1898 & 6744 & 91.04 & 2015 & 89.67 & 347 & 91.31 & 4.8 & 85.71\end{array}$

$\begin{array}{lllllllll}1899 & 67411 & 91 & 2118 & 98.22 & 387 & 101.84 & 61 & 108.92\end{array}$

$\begin{array}{lllllllll}1900 & 8165 & 110.23 & 2405 & 107.03 & 455 & 119.73 & 76 & 135.71\end{array}$

Zoowel in 1892 als in 1900 is er dus niet alleen van de aanzienlijke nalatenschappen, maar in al de vier groepen een belangrijke stijging.

In den winter van 1891-1892 heerschte de influenza en ook in dien van 1899-1900 eischten de acute ziekten der ademhalingswerktuigen vele offers.

Zou de hypothese gewaggd zijn, dat de hooge opbrengst der successiebelasting èn in 1892 èn in 1900 daarin haar verklaring vindt?

Amsterdam, December 1901.

Lt. 